\title{
Analiza możliwości poprawy bezpieczeństwa eksploatacji instalacji gazowych - przyczyny wypadków oraz rozwiązania pozwalające na minimalizację ich liczby
}

\begin{abstract}
Artykuł przedstawia analizę przyczyn wypadków powstałych przy użytkowaniu instalacji gazowych na gaz ziemny i propan-butan (gaz płynny) oraz nieprawidłowości związane z ich kontrolą i eksploatacją. Omówiono rozwiązania pozwalające zwiększyć bezpieczeństwo użytkowania instalacji i urządzeń gazowych oraz zaprezentowano nowoczesne materiały do budowy instalacji gazowych dostępne na rynku polskim i stosowane w krajach Europy czy USA.
\end{abstract}

Słowa kluczowe: zabezpieczenie instalacji, instalacja gazowa, butle gazowe, bezpieczeństwo.

\section{Analysis of the possibilities for improving the safety and reliability of gas installations - the causes of accidents and solutions which allow their minimization}

\begin{abstract}
The article presents an analysis of the causes of accidents resulting from the use of gas installations for natural gas and propane-butane (LPG) and abnormalities associated with the control and use of these facilities. Solutions to improve the safety of gas installations and appliances, as well as modern materials available on the market for the construction of gas installations available on the Polish market and used in European countries or the US were discussed and presented.
\end{abstract}

Key words: security system, gas installation, gas cylinders, safety.

\section{Analiza przyczyn wypadków związanych z eksploatacją instalacji gazowych różnego typu}

W dobie nadchodzących zmian związanych z ograniczaniem stosowania paliw stałych w celach grzewczych coraz większe znaczenie jako paliwo mają gaz ziemny i płynny. Gazy te są źródłem energii relatywnie najbardziej przyjaznym ekologicznie, jednak przy ich wykorzystywaniu należy spełnić szereg wymagań związanych z ich bezpiecznym użytkowaniem. W Polsce około 30\% zużycia gazu przypada na gospodarstwa domowe. Ponad 5 milionów rodzin korzysta z butli gazowych, co stanowi około $40 \%$ gospodarstw domowych. Gaz używany jest głównie do celów grzewczych i do gotowania [4].

Niebezpieczeństwo związane z użytkowaniem gazu może wystąpić głównie w przypadku nieprzestrzegania obowiązujących przepisów oraz w wyniku działań celowych.

Rozporządzenie Ministra Infrastruktury w sprawie warunków technicznych, jakim powinny odpowiadać budyn- ki i ich usytuowanie w rozdziale 7 przedstawia m.in. wymagania i ograniczenia stosowania instalacji gazowych. Często naruszanym ograniczeniem jest łamanie $§ 157$ p. 6, który mówi: „Zabrania się stosowania w jednym budynku gazu płynnego i gazu z sieci gazowej" [12].

Na właścicielach lub zarządcach nieruchomości spoczywa obowiązek przeprowadzania kontroli instalacji gazowych, które powinny być realizowane w okresie wiosennym wraz z kontrolami przewodów wentylacyjnych i kominowych. Procedury wykonywania kontroli opisane są w przepisach i normach $[12,14]$.

O ile przepis ten przestrzegany jest w budynkach wielorodzinnych, w budynkach jednorodzinnych już nie. Dzieje się tak za przyczyną błędnej interpretacji przepisów prawa budowlanego. Mianowicie art. 62 ust. 1 ustawy Prawo budowlane mówi: 
„Obiekty budowlane powinny być w czasie ich użytkowania poddawane przez właściciela lub zarządcę kontroli:

1) okresowej, co najmniej raz $\mathrm{w}$ roku, polegającej na sprawdzeniu stanu technicznego:

a) elementów budynku, budowli i instalacji narażonych na szkodliwe wpływy atmosferyczne i niszczące działania czynników występujących podczas użytkowania obiektu,

b) instalacji i urządzeń służących ochronie środowiska,

c) instalacji gazowych oraz przewodów kominowych (dymowych, spalinowych i wentylacyjnych)" [19].

W ust. 2 natomiast wprowadzono zapis mówiący: „Obowiązek kontroli, o której mowa w ust. 1 pkt 1 lit. a, nie obejmuje właścicieli i zarządców..." wymienionych w dalszej części ust. 2 obiektów budowlanych. Tak więc poprzez zapis w art. 62 ustawodawca zwalnia z obowiązku przeprowadzania kontroli właścicieli i zarządców między innymi budynków mieszkalnych jednorodzinnych, lecz tylko w zakresie sprawdzenia stanu technicznego ,elementów budynku, budowli i instalacji narażonych na szkodliwe wpływy atmosferyczne i niszczące działania czynników występujących podczas użytkowania obiektu", a nie w zakresie wymienionym w ust. 1 pkt 1 lit. c, dotyczącym instalacji gazowych i przewodów kominowych.

Zatem kontrola instalacji gazowych i przewodów kominowych powinna być przeprowadzana okresowo co najmniej raz w roku również w budynkach jednorodzinnych [19].

Kontrole powinny być wykonane przez upoważniony personel, posiadający odpowiednie uprawnienia energetyczne grupy 3 - Urzadzenia, instalacje i sieci gazowe wytwarzajace, przetwarzajace, przesyłajace, magazynujace i zużywajace paliwa gazowe [16] oraz wyposażony w odpowiednie przyrządy pomiarowe.

Uwaga: Do kierowania pracami i do ich nadzorowania wymagane jest świadectwo kwalifikacyjne „D”, natomiast do prac na stanowisku eksploatacji w zakresie: obsługi, konserwacji, remontów, montażu wymagane jest świadectwo kwalifikacyjne ,E”.

Na rynku istnieje wiele przyrządów pozwalających kontrolować szczelność instalacji gazowych. Jednym z nich jest system laserowy omawiany w osobnych opracowaniach [5].

Kontroli powinny być poddane główne elementy instalacji gazowych:

- połączenia gwintowane,

- przejścia przez ściany budynków,

- dostęp do zaworów i kurków,

- stężenie gazu w pomieszczeniach technicznych, piwnicach,

- stężenie gazu na najwyższych piętrach,

- działanie i stan techniczny urządzeń gazowych w pomieszczeniach technicznych, mieszkalnych,
- zastosowane przewody podłączeniowe urządzeń gazowych, - zabezpieczenie antykorozyjne przewodów instalacji gazowych,

- zastosowane materiały i technologie wykonania instalacji gazowej,

- skuteczność działania instalacji wentylacyjnych.

W przypadku korzystania w mieszkaniach z gazów płynnych, np. najpopularniejszych butli do $11 \mathrm{~kg}$, rozporządzenie w sprawie warunków technicznych użytkowania budynków mieszkalnych w rozdziale 14 § 48 pkt 4 mówi: „Sprawdzenie szczelności przy wymianie butli gazowej przeprowadza użytkownik instalacji, zgodnie z instrukcją otrzymaną od rozprowadzającego butle, lub przedstawiciel dostawcy gazu, w przypadku gdy z użytkownikiem lokalu została zawarta umowa o dostarczanie gazu w butlach" [18].

Ponadto $\S 49$ stanowi: ,W przypadku stosowania przewodu elastycznego do połączenia pojedynczego urządzenia gazowego z reduktorem ciśnienia gazu na butli, przewód taki powinien mieć oznaczoną graniczną datę użytkowania. Jeżeli termin użytkowania upłynął, przewód należy wymienić na nowy" [18].

Te dwa najważniejsze, wydawałoby się, punkty są bardzo rzadko przestrzegane, co może być przyczyną wypadków.

Na rysunkach 1 i 2 przedstawiono dane dotyczące katastrof budowlanych związanych z użytkowaniem gazu.

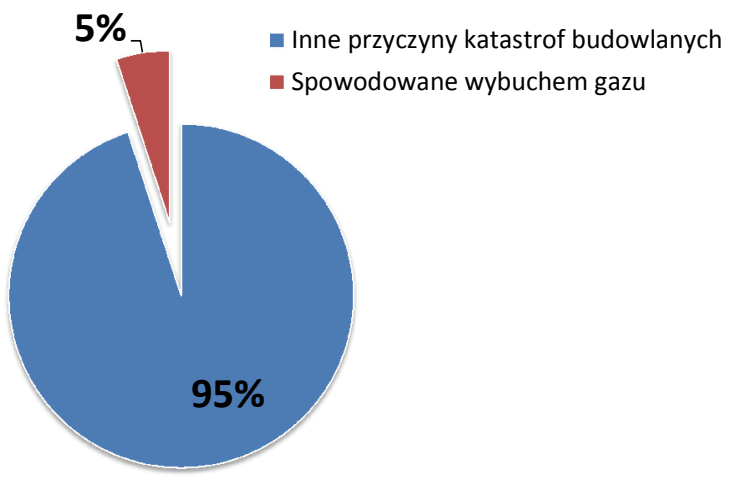

Rys. 1. Częstość katastrof budowlanych spowodowanych wybuchem gazu (opracowano na podstawie [1])

- Katastrofy spowodowane wybuchem gazu płynnego - Katastrofy spowodowane wybuchem gazu ziemnego

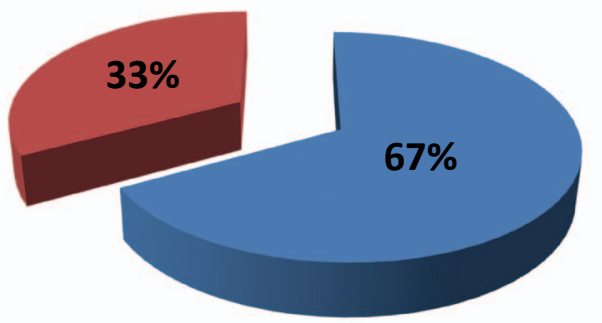

Rys. 2. Katastrofy spowodowane wybuchem gazu (opracowano na podstawie $[1,9]$ ) 
Wśród katastrof budowlanych te spowodowane wybuchem gazu stanowią zaledwie 5\%. Skutki tych katastrof jednak są niejednokrotnie tragiczne. Jak przedstawiono na rysunku 3 , liczba zabitych stanowi 14\%, a rannych 39\% $\mathrm{z}$ wszystkich katastrof budowlanych.

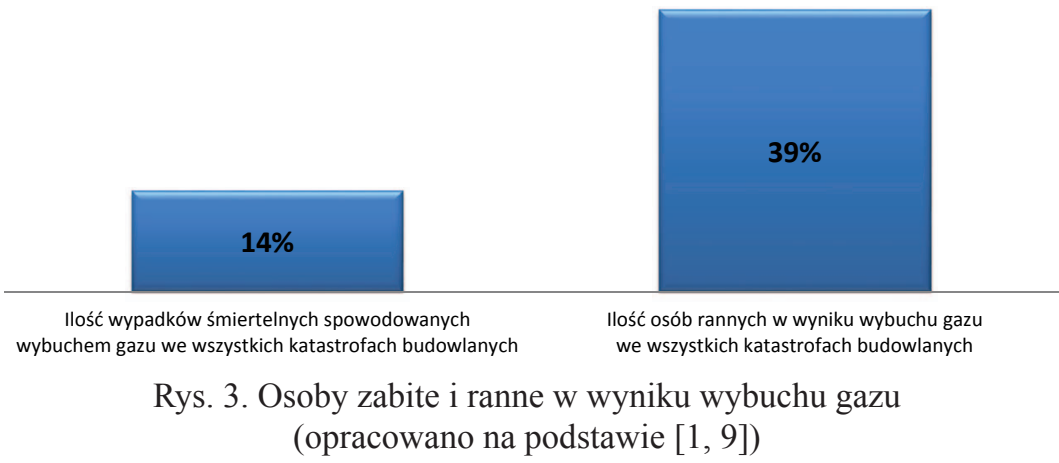

Wypadki związane z użytkowaniem instalacji gazowych

Obecnie przepisy [12] ograniczają stosowanie instalacji gazowych w budynkach wyższych niż $35 \mathrm{~m}$ nad poziomem terenu. W takich budynkach zezwala się na montaż instalacji jedynie w pomieszczeniach technicznych, w których zainstalowane są urządzenia gazowe. W budynkach o wysokości ponad $25 \mathrm{~m}$ montaż instalacji jest dopuszczalny, ale tylko za zgodą właściwego wojewódzkiego komendanta Państwowej Straży Pożarnej.

W poprzednich latach montaż instalacji gazowych dopuszczany był również w wysokich budynkach, a instalacje wykonywano w technologiach obecnie niedozwolonych.

Wypadki powstałe na skutek wybuchu gazu mogą występować zależnie lub niezależnie od człowieka. Na bezpieczeństwo instalacji gazowych wpływ mają nieprawidłowości powstałe na etapie:

- projektowania - niewłaściwy dobór materiałów, nieprzestrzeganie wymagań technicznych określonych w przepisach,

- wykonywania - nieprzestrzeganie rozwiązań z projektu,

- eksploatacji - samowolna przebudowa instalacji.

Szczególną uwagę należy zwrócić na:

- przyłącza - wadliwe wykonanie połączeń PE/stal, wadliwe kurki główne, wadliwe połączenia spawane,

- reduktory ciśnienia gazu - pęknięcia obudowy, nieprawidłowy dobór,

- przewody wewnętrznej instalacji gazowej - wadliwie wykonane połączenia gwintowane, zbyt duża liczba kształtek, kurków,

- gazomierze - wady techniczne urządzenia pomiarowego, nieprawidłowy montaż, niezgodna z przepisami lokalizacja gazomierza,

- przewody kominowe (dymowe, spalinowe, wentylacyjne) - zbyt małe przekroje, korozja przewodów spalinowych, nieszczelności połączeń przewodów spalinowych. $\mathrm{Na}$ te wszystkie aspekty należy zwrócić uwagę na etapie prowadzonych odbiorów instalacji gazowych w budynkach. Zlekceważenie ich na tym etapie może mieć tragiczne w skutkach konsekwencje.

\section{Wypadki niezależne od czlowieka}

Użytkowanie instalacji gazowej niesie za sobą obowiązki i zagrożenia. Nie wszystkie awarie i wypadki związane z używaniem gazu zależne są bezpośrednio od człowieka. Istnieją sytuacje, których nie można przewidzieć, m.in. zdarzenia losowe, następstwa innych prac wykonywanych w pobliżu instalacji bądź sieci gazowych. Zdarza się, że do wypadków związanych z wybuchem gazu dochodzi w budynkach, w których nie ma instalacji gazowej (migracja gazu).

Przyczyną wypadków występujących niezależnie od działań człowieka mogą być:

- rozszczelnienie instalacji gazowych, szczególnie w starych budynkach, gdzie instalacje były łączone na gwint,

- awaria urządzeń gazowych, np. podgrzewaczy wody, kuchenek,

- migracja gazu do wnętrza budynku wzdłuż innych instalacji technologicznych, przy wystąpieniu rozszczelnienia przyłącza gazowego lub sieci gazowej,

- migracja gazu do wnętrza budynku przez grunt, przy wystąpieniu rozszczelnienia sieci gazowej przechodzącej obok budynku,

- uszkodzenie instalacji na skutek zdarzeń losowych (wichury, zawalenia budynku),

- awaria urządzeń redukujących ciśnienie gazu,

- urządzenia nieposiadające zabezpieczeń odcinających gaz w przypadku zgaszenia płomienia.

\section{Wypadki zależne od cztowieka}

Niestety wiele wypadków związanych z użytkowaniem gazu wynika z działań celowych, zaniedbań lub braku ostrożności. Do najczęstszych z nich możemy zaliczyć:

- celowe rozszczelnienia instalacji gazowej,

- kradzieże gazu,

- brak kontroli instalacji gazowej,

- brak kontroli instalacji gazowej w wyniku jej niedostępności,

- niesprawna wentylacja lub jej brak - zatrucie tlenkiem węgla. 
Trudno udowodnić celowość rozszczelnienia instalacji jednak, w niektórych przypadkach po przeprowadzeniu wywiadu środowiskowego z dużym prawdopodobieństwem można przyjąć taką tezę.

Przykładem może być wybuch gazu, który wystąpił w domu jednorodzinnym w Bydgoszczy. Wybuch był tak silny, że uszkodził dwa budynki oraz przedszkole, które znajdowały się w sąsiedztwie. W wyniku eksplozji śmierć poniósł mężczyzna. Jego ciało znaleziono w kuchni budynku, w którym nastąpiła eksplozja. Z doniesień sąsiadów wynikało, że mężczyzna kilkakrotnie groził samobójstwem [6]. Innym przypadkiem była eksplozja gazu w domu jednorodzinnym zasilanym z miejskiej sieci gazowej [2].

Zdarzają się również wypadki powstałe na skutek ingerencji w instalację gazową podczas kradzieży gazu. O takich przypadkach uzyskano informacje od służb gazowniczych. Jednym z incydentów było rozkręcenie podłączeń gazomierza i kradzież gazu poprzez dętkę rowerową czy też wąż ogrodowy. Dzieje się tak zarówno w domach, jak i w blokach, gdzie naraża się na utratę zdrowia lub śmierć sąsiadów. W doniesieniach medialnych można również znaleźć informację o eksplozjach gazu w urządzeniach gazowych, które miały miejsce w wyniku braku kontroli ich sprawności.

Najczęstszym wypadkiem związanym z użytkowaniem gazu, a zależnym od użytkownika jest zatrucie tlenkiem węgla. Bardzo często do tych zdarzeń dochodzi w okresie jesienno-zimowym. Przyczyną jest brak sprawnej wentylacji lub zbyt szczelne drzwi czy okna w mieszkaniu, co powoduje tzw. cofkę, czyli sytuację, gdy spaliny z urządzeń gazowych, np. podgrzewaczy, cofają się do pomieszczenia. W wysokich blokach, gdzie przewody spalinowe są wspólne dla niektórych mieszkań, spaliny mogą cofać się do sąsiedniego mieszkania. Niedopuszczalne jest również montowanie wentylacji wymuszonej w pomieszczeniu $\mathrm{z}$ urządzeniem gazowym posiadającym otwarte palenisko. Wszystkim tym zdarzeniom można zapobiegać, uświadamiając ludzi i przeprowadzając okresowe kontrole.

\section{Wypadki zwiazane z użytkowaniem gazu propan-butan}

Zasilanie gazem propan-butan budynków można realizować poprzez:

- butle do $11 \mathrm{~kg}$,

- butle do $33 \mathrm{~kg}$,

- baterie butli do 10 szt.,

- zbiorniki do $10 \mathrm{~m}^{3}$,

- zbiorniki o pojemności $10 \div 100 \mathrm{~m}^{3}$,

- zespół zbiorników o pojemności $10 \mathrm{~m}^{3} \mathrm{w}$ liczbie nieprzekraczającej 6 szt.

W przypadku użytkowania butli do $11 \mathrm{~kg} \mathrm{w}$ mieszkaniu dopuszczalne jest instalowanie ich w liczbie maksymalnie
Tablica 1. Przykładowy wzrost ciśnienia gazu w zależności od jego temperatury [3]

\begin{tabular}{|c|c|}
\hline $\begin{array}{c}\text { Temperatura gazu w butli } \\
{\left[{ }^{\circ} \mathrm{C}\right]}\end{array}$ & $\begin{array}{c}\text { Ciśnienie w butli } \\
{[\mathrm{MPa}]}\end{array}$ \\
\hline 0 & 1,0 \\
\hline 10 & 6,5 \\
\hline 20 & 13,0 \\
\hline 30 & 20,0 \\
\hline 40 & 27,0 \\
\hline 50 & 33,0 \\
\hline
\end{tabular}

dwóch sztuk. Butle ważące $33 \mathrm{~kg}$ powinny być umieszczone na zewnattrz budynku, w miejscu utwardzonym, oznakowanym, pod zadaszeniem. Mogą być instalowane w bateriach do 10 sztuk. Butle powinny być połączone ze sobą rurami bez szwu, a połączenia spawane. Nie dopuszcza się stosowania połączeń z rur miedzianych lub z tworzywa. Butle powinny być zlokalizowane w miejscu niepozwalającym na nagrzewanie się ich powyżej temperatury $35^{\circ} \mathrm{C}$ [12]. Maksymalna ilość gazu w butli nie powinna przekroczyć $85 \%$ pojemności butli. Warunek ten wynika z właściwości gazu. Wraz ze wzrostem temperatury gaz się rozpręża i powoduje zwiększenie ciśnienia w butli do wartości niebezpiecznych (w skrajnym przypadku może dojść do rozerwania butli) [12].

W tablicy 1 przedstawiono przykładowy wzrost ciśnienia w butli wypełnionej propanem.

Dopuszcza się instalowanie oraz przechowywanie butli lub baterii butli w specjalnie przystosowanych do tego pomieszczeniach. Wentylacja pomieszczenia powinna być umiejscowiona maksymalnie $0,15 \mathrm{~m}$ od powierzchni podłogi. Szczególną uwagę należy zwrócić na usytuowanie butli w stosunku do otworów wentylacyjnych, okien, drzwi oraz studzienek kanalizacyjnych. Polskie przepisy nie regulują odległości instalowania butli od tych elementów.

Zgodnie z przepisami obowiązującymi w Polsce [18] w przypadku zasilania budynków z zewnętrznych zbiorników gazu, o pojemności najczęściej $10 \mathrm{~m}^{3}$, kontrolę instalacji gazowej zasilającej należy przeprowadzać regularnie. Zbiorniki te powinny być wyposażone w zawory bezpieczeństwa, zawory odcinające wypływ gazu, poziomowskazy, manometry oraz węzły redukcji ciśnienia.

Zbiorniki o pojemności powyżej $10 \mathrm{~m}^{3}$ powinny posiadać przewody umieszczone co najmniej $3 \mathrm{~m}$ ponad poziom terenu, odprowadzające fazę gazową z zaworów bezpieczeństwa. Powinny posiadać ochronę przed korozją realizowaną poprzez powłoki antykorozyjne oraz system ochrony katodowej. Zbiorniki takie podlegają kontroli Urzędu Dozoru Technicznego [7].

Na rynku w obrocie znajduje się ponad 10 milionów butli gazowych do $11 \mathrm{~kg}$. Gaz z butli wykorzystywany do ogrze- 
wania lub gotowania użytkowany jest najczęściej w regionach niezgazyfikowanych. Polska Organizacja Gazu Płynnego zanotowała znaczny wzrost zdarzeń niebezpiecznych związanych z użytkowaniem butli gazowych. Średnio raz w tygodniu dochodzi do zdarzenia, w którym tracone są dobra materialne, zdrowie, a nawet życie ludzi.

Prawidłowo napełniona butla powinna mieć kolor inny niż żółty i czerwony, który jest zastrzeżony dla urządzeń gaśniczych.

Butla powinna posiadać:

- jednolitą barwę,

- umieszczoną tabliczkę z informacją o wadze butli, maksymalnej ilości gazu, datę legalizacji,

- instrukcję bezpieczeństwa/obsługi w postaci naklejki $\mathrm{z}$ informacją o gazie, firmie napełniającej, $\mathrm{z}$ telefonem kontaktowym,

- zabezpieczenie na wylocie zaworu, w sytuacji przypadkowego odkręcenia,

- plombę w postaci folii termokurczliwej na zaworze, nieuszkodzoną uszczelkę $\mathrm{w}$ gnieździe zaworu.

Przy użytkowaniu butli gazowych do $11 \mathrm{~kg}$ należy również zwrócić uwagę na instalację gazową, której elementami są:

- reduktor,

- przewód gazowy elastyczny.

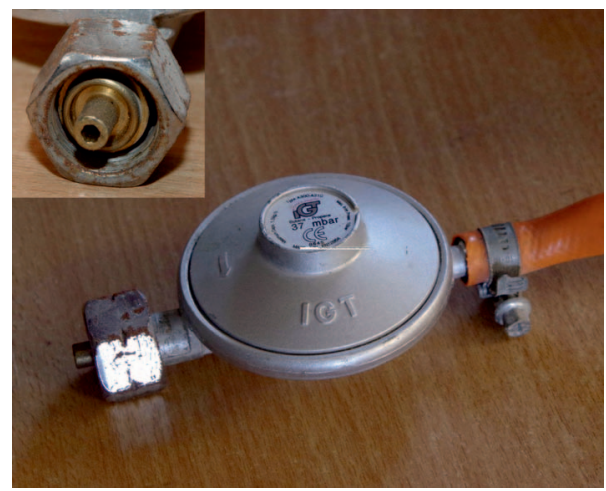

Fot. 1. Reduktor wraz z przewodem (fot. T. Minor)

Zgodnie z rozporządzeniem Ministra Administracji w sprawie warunków technicznych użytkowania budynków mieszkalnych, $\S 49$ [18], przewód powinien być oznakowany w sposób czytelny, a w znakowaniu powinna znaleźć się data, do kiedy należy przewód wymienić na nowy.

Przykładowe oznakowanie przewodu gazowego do podłączania butli gazowej, dostępnego na rynku w Polsce, przedstawia fotografia 2. Na przewodzie naniesiona została data produkcji, a nie data ważności przewodu, jak wymagają przepisy. Spośród kilkunastu przewodów dostępnych w sprzedaży każdy miał nadrukowaną datę produkcji, a nie datę ważności przewodu, więc przewody te nie powinny znajdować się w sprzedaży.

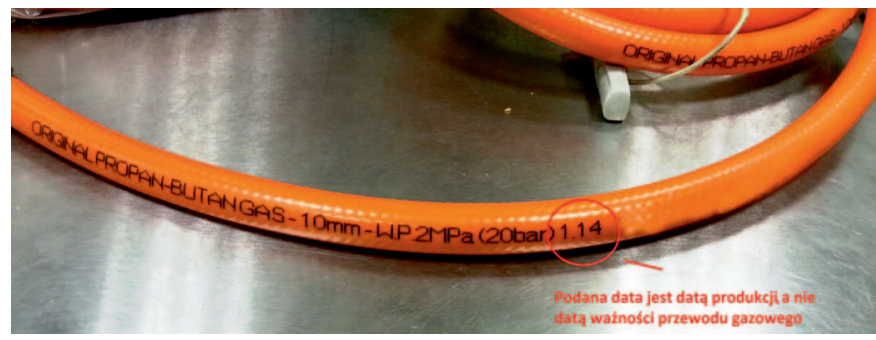

Fot. 2. Znakowanie przewodu gazowego butli propan-butan (fot. T. Minor)

Mając na uwadze powyższe zdarzenia, należy rozważyć propozycję, aby wymiana butli o wadze do $11 \mathrm{~kg}$ wykonywana była tylko przez wykwalifikowaną osobę, posiadającą odpowiednie uprawnienia oraz urządzenia sprawdzające szczelność połączeń.

\section{Zdarzenia zależne od człowieka}

W pierwszej kolejności omówiono przyczyny wypadków związanych z użytkowaniem butli gazowych propan-butan zależnych od człowieka. Jest ich znacznie więcej niż tych powstałych w wyniku zdarzeń losowych.

Najczęstszymi przyczynami zdarzeń niebezpiecznych związanych z gazem propan-butan mogą być:

- nieprawidłowe przechowywanie butli,

- brak uszczelek lub zużyte uszczelki w zaworze butli,

- nieprzestrzeganie przepisów dotyczących montażu, użytkowania, sprawdzenia szczelności połączeń,

- brak wymiany zaworów przy butli,

- brak wymiany przewodów instalacji butli gazowych zasilających urządzenia,

- brak wentylacji pomieszczenia zgodnej z wymaganiem przepisów regulujących przechowywanie butli z propanem-butanem (wywiew w dolnej części pomieszczenia),

- brak sprawnej wentylacji - zatrucia tlenkiem węgla,

- użytkowanie niesprawnych, nieatestowanych butli,

- skorodowane butle gazowe,

- brak kontroli szczelności instalacji gazowej,

- przechowywanie butli w piwnicach, na strychach.

Często montowane są butle stare i zardzewiałe, $\mathrm{z}$ uszkodzonymi uszczelkami. Pod żadnym pozorem nie wolno sprawdzać szczelności połączeń zapaloną zapałką czy też zapalniczką, a do takich sytuacji również dochodzi. Wszelkie wątpliwości, podejrzenia ulatniania się gazu należy niezwłocznie zgłosić dostawcy butli lub wykwalifikowanej osobie, która na miejscu sprawdzi instalacje oraz butle i usunie ewentualne wady i usterki. Przewody instalacji gazowej, zwłaszcza elastyczne, powinny być wymienione przed upływem daty umieszczonej na przewodzie. Niestety zalecenia te nie są przestrzegane i mało kto zwraca uwagę na datę ważności przewodu gazowego, a butle są podłączane przez osoby 


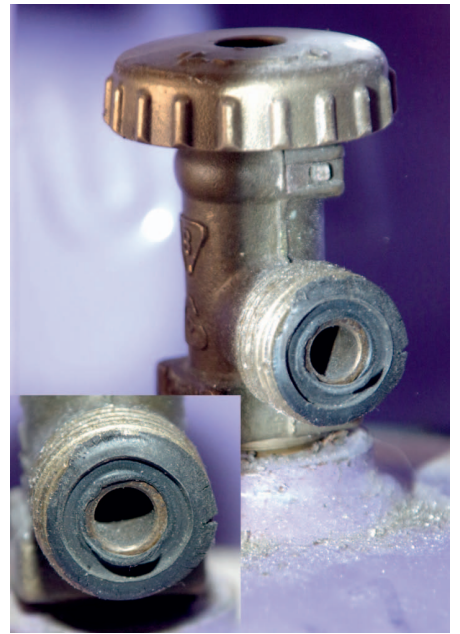

Fot. 3. Zawór butli $11 \mathrm{~kg}$ ze zużytą uszczelką (fot. T. Minor)

nieupoważnione, najczęściej lokatorów. Sprawą często pomijaną przy kontrolach budynków jest usytuowanie otworów wentylacyjnych $\mathrm{w}$ pomieszczeniach $\mathrm{z}$ butlami gazowymi. Powszechne zaniedbanie architektoniczne to oddawanie budynków wielorodzinnych, w których będą użytkowane kuchenki zasilane z butli, bez otworów wentylacyjnych w kuchni umieszczonych przy podłodze.
Butle przechowywane są często w miejscach narażonych na wysokie temperatury (pow. $35^{\circ} \mathrm{C}$ ) oraz niekorzystne warunki atmosferyczne. W wyniku nieprawidłowego przechowywania dochodzi do uszkodzenia zaworów i rozszczelnienia butli. Po podłączeniu nie jest sprawdzana szczelność połączeń.

Zbiorniki o pojemności powyżej $10 \mathrm{~m}^{3}$ często posiadają systemy ochrony przed korozją, które są niewłaściwie obsługiwane lub w ogóle nienadzorowane.

\section{Zdarzenia niezależne od czlowieka}

Przyczynami zdarzeń niezależnych od człowieka są najczęściej:

- wada konstrukcyjna butli, zaworów,

- wady materiałowe.

Należy podkreślić, że w przypadku instalacji zasilanych gazem płynnym wady konstrukcyjne są niezmiernie rzadko przyczyną wypadku. Rozerwanie butli może nastąpić w wyniku przepełnienia, co i tak w gruncie rzeczy jest spowodowane błędem ludzkim. Obecnie przepisy zabraniają napełniania butli gazowych na stacjach paliw, a jedną z przyczyn takiej decyzji było właśnie ich przepełnianie [15].

\section{Analiza stanu techniki armatury zabezpieczającej i jej dostępności na rynku UE oraz analiza materiałów do budowy instalacji gazowych}

\section{Podstawowe detektory domowe}

$\mathrm{Na}$ rynku istnieją nowoczesne urządzenia i rozwiązania pozwalające na zabezpieczenie instalacji gazowych przed niekontrolowanym wypływem gazu oraz pozwalające odpowiednio wcześniej zapobiec, często tragicznym w skutkach, wypadkom. Wiele rozwiązań jest bezpośrednio dostępnych na rynku dla użytkowników i możliwych do stosowania bez ingerencji w instalacje gazowe. Najprostszymi i ogólnie dostępnymi urządzeniami są detektory gazu. Należy je umieścić w pobliżu urządzeń gazowych lub butli gazowych. W przypadku rozszczelnienia instalacji urządzenie takie zareaguje w odpowiednim czasie, dając głośny sygnał akustyczny, pozwalając w ten sposób użytkownikowi na podjęcie odpowiednich działań. Detektory te mogą współpracować również z elektrozaworami odcinającymi.

Należy zwrócić uwagę na stosunkowo małą popularność detektorów propanu-butanu, a powinny być one $-\mathrm{z}$ racji błędów budowlanych dotyczących wentylacji - obowiązkowo montowane w pomieszczeniach, w których stosuje się butle do $11 \mathrm{~kg}$.

\section{Detektory tlenku węgla}

Obecne rozwiązania konstrukcyjne elementów budynków znacznie różnią się jakością od tych stosowanych kilkadziesiąt lat temu. Mówimy tu o oknach i drzwiach, ponie- waż to one najczęściej zaburzają systemy wentylacji w budynkach. Zbyt szczelne okna i drzwi niedostatecznie napowietrzają pomieszczenia, w wyniku czego powietrze z zewnątrz zaczyna być dostarczane przez przewody spalinowe, cofając często przy tym spaliny do pomieszczeń, w których znajdują się gazowe podgrzewacze wody lub piece na paliwa stałe. Przy niesprawnej lub słabej instalacji wentylacyjnej często dochodzi do tragicznych w skutkach zatruć tlenkiem węgla. Tlenek węgla to gaz bardzo zdradliwy, ponieważ jest bezwonny. Objawy zatrucia tlenkiem węgla są często lekceważone. Tablica 2 przedstawia najczęstsze objawy przy zatruciu CO w zależności od jego stężenia w powietrzu.

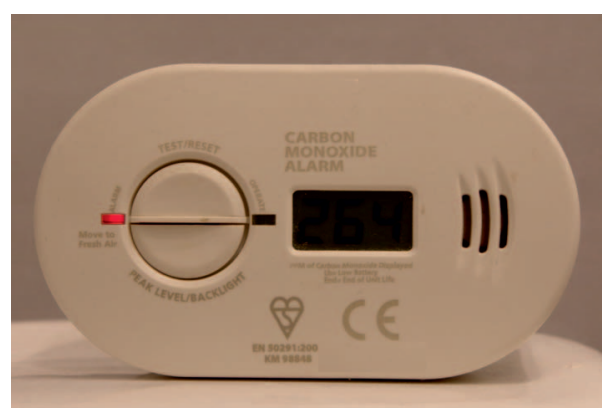

Fot. 4. Detektor tlenku węgla (sygnalizacja przekroczenia dopuszczalnego poziomu) (fot. T. Minor) 
Aby zapobiec takim zdarzeniom, należy w miejscu, w którym zainstalowane jest urządzenie gazowe lub na paliwo stałe, oraz najlepiej dodatkowo w pomieszczeniu sypialnym, zamontować czujnik tlenku węgla, tzw. czadu. Detektor po wykryciu niebezpiecznej wartości uruchomi głośną sygnalizację akustyczną i w zależności od wersji pokaże stężenie $\mathrm{CO}$ w powietrzu. Wersje posiada- jące wyświetlacz umożliwiają sprawdzanie maksymalnego zarejestrowanego stężenia $\mathrm{CO}$ w powietrzu, ponieważ nie każdy poziom stężenia uruchamia alarm, a stężenie CO może być większe niż 0 ppm. Pozwala to zwrócić uwagę użytkownikowi na niedostateczną wydajność instalacji wentylacyjnej. Zaawansowane czujniki tlenku węgla mogą współpracować z elektrozaworami odcinającymi gaz.

Tablica 2. Objawy zatrucia tlenkiem węgla w zależności od jego stężenia w powietrzu [11]

\begin{tabular}{|c|l|}
\hline $\begin{array}{c}\text { Stężenie objętościowe } \\
\text { CO w powietrzu }\end{array}$ & \multicolumn{1}{c|}{ Objawy zatrucia } \\
\hline $\begin{array}{c}100 \div 200 \mathrm{ppm} \\
(0,01 \div 0,02 \%)\end{array}$ & lekki ból głowy przy ekspozycji przez $2 \div 3$ godziny \\
\hline $400 \mathrm{ppm}(0,04 \%)$ & silny ból głowy, zaczynający się około 1 godzinę po wdychaniu tego stężenia \\
\hline $800 \mathrm{ppm}(0,08 \%)$ & zawroty głowy, wymioty i konwulsje po 45 minutach wdychania; po dwóch godzinach trwała śpiączka \\
\hline $1600 \mathrm{ppm}(0,16 \%)$ & silny ból głowy, wymioty, konwulsje po 20 minutach; zgon po dwóch godzinach \\
\hline $3200 \mathrm{ppm}(0,32 \%)$ & intensywny ból głowy i wymioty po $5 \div 10$ minutach; zgon po 30 minutach \\
\hline $6400 \mathrm{ppm}(0,64 \%)$ & ból głowy i wymioty po $1 \div 2$ minutach; zgon w niecałe 20 minut \\
\hline $12800 \mathrm{ppm}(1,28 \%)$ & \begin{tabular}{l} 
utrata przytomności po $2 \div 3$ wdechach; śmierć po \\
\hline
\end{tabular} \\
\hline
\end{tabular}

\section{Urządzenia zabezpieczające przed wypływem gazu}

\section{Standardowe zabezpieczenia przeciwwyphywowe w urzadzeniach gazowych}

Jednym z możliwych rozwiązań jest zastosowanie zaworów zabezpieczających przed nagłym wypływem gazu. Podstawowe takie zabezpieczenie montuje się w nowych kuchenkach gazowych i pozostałych gazowych urządzeniach grzewczych. W przypadku zgaszenia płomienia czujnik odcina dopływ gazu, zabezpieczając pomieszczenie przed gromadzeniem się w nim niespalonego gazu.

\section{Urzadzenia na instalacji gazowej zabezpieczające przed naglym wyplywem gazu}

W punkcie tym opisany został system bardziej rozbudowany. Zawór odcinający (ogranicznik przepływu gazu) montowany jest na instalacji gazowej, najczęściej przy gazomierzu. Zawór dobiera się do maksymalnego przepływu gazu w zainstalowanych urządzeniach na instalacji, przy ich maksymalnym obciążeniu cieplnym. W przypadku rozszczelnienia instalacji i nagłego wypływu zawór odcina dopływ gazu do urządzeń.

We Francji instalacje w budynkach wielorodzinnych pracują przy ciśnieniach 5 bar. Przed każdym urządzeniem spalającym zamontowany jest reduktor ciśnienia. Rozwiązanie to jest zgodne z normą EN 1775:2007 (PN-EN 1775:2009) i w przypadku nagłego rozszczelnienia instalacji lub jej uszkodzenia elementy zabezpieczające reagujące na nagły wypływ działają pewniej i szybciej niż przy niskich ciśnieniach.

\section{Automatyczne systemy odcinające}

Bardziej zaawansowanymi systemami są automatyczne systemy zabezpieczeń, stosowane najczęściej w kotłowniach budynków wielorodzinnych. Są to systemy zbudowane z wielu urządzeń, montowanych zarówno w instalacji gazowej, jak i w sąsiedztwie urządzeń gazowych.

Podstawowym wyposażeniem takiego systemu są:

- elektrozawór odcinający gaz - montowany na instalacji gazowej,
- detektor gazu - montowany w pobliżu urządzeń gazowych,

- centrala systemu,

- sygnalizator akustyczny - umiejscowiony najczęściej na zewnątrz budynku,

- wyłącznik ręczny zbijakowy.

To rozbudowany system odcinający. Jednym z ważniejszych elementów systemu jest detektor umieszczany nad urządzeniem gazowym. Może to być sensor różnych gazów, np. 


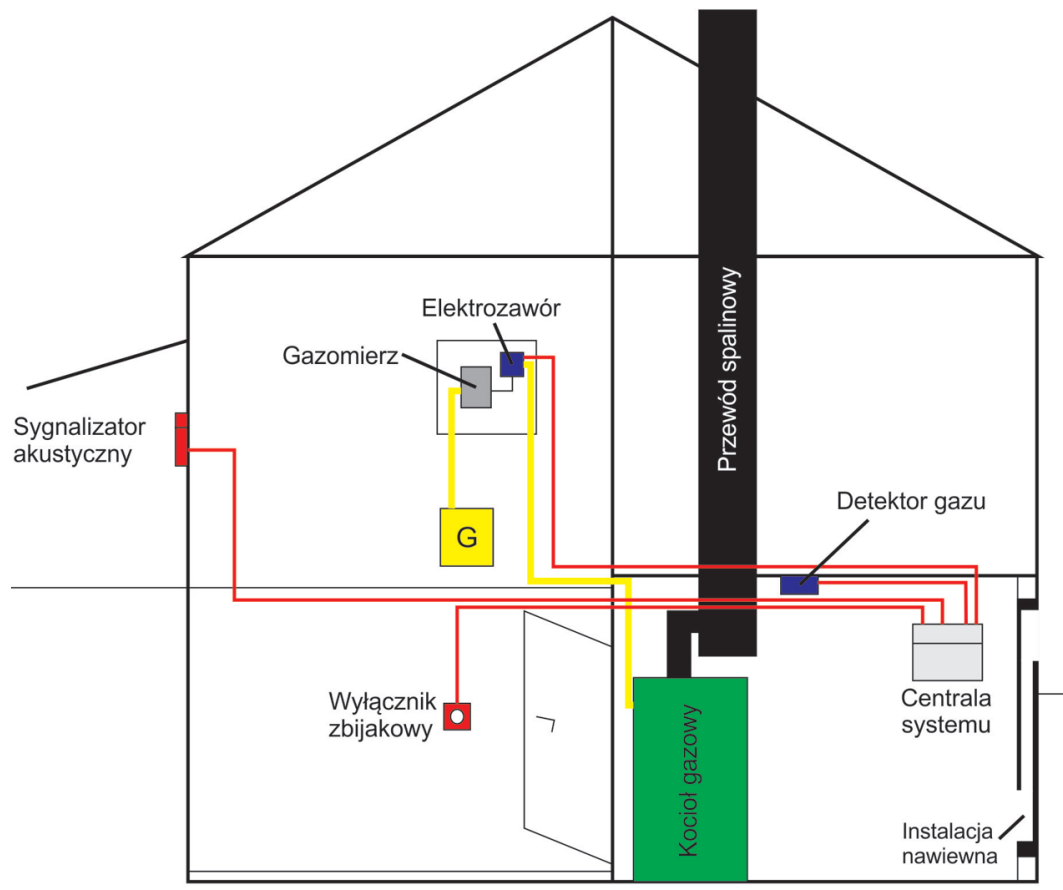

Rys. 4. Schemat poglądowy montażu automatycznego systemu odcinania dopływu gazu

stępuje automatycznie. Wykonać to może tylko osoba upoważniona. Systemy te mają możliwość komunikacji poprzez GSM, umożliwiając powiadomienie osób odpowiedzialnych, służb ratunkowych itp.

Innym dostępnym rozwiązaniem jest zastosowanie detektora gazu, np. metanu, w miejscu zainstalowanego urządzenia gazowego, np. kuchenki gazowej czy też podgrzewacza wody. Detektor współpracuje z elektrozaworem zamontowanym za gazomierzem. W chwili pojawienia się nieszczelności i możliwości powstania atmosfery wybuchowej detektor uruchamia elektrozawór, odcinając dopływ gazu do mieszkania lub domu. Możliwe jest zastosowanie dwóch detektorów, np. tlenku węgla i gazu wybuchowego, sterujących elektrozaworem. Elektrozawór po zadziałaniu nie powróci sam do pierwotnej pozycji, konieczne jest uruchomienie go ręcznie przez człowieka.

Elektrozawory oferowane na rynku mają róż-

tlenku węgla, gazów wybuchowych itp. W przypadku użycia detektora tlenku węgla w chwili nieprawidłowego spalania lub rozszczelnienia instalacji kominowej detektor przekazuje sygnał do centrali systemu, centrala uruchamia sygnalizator akustyczno-świetlny oraz odcina dopływ gazu do urządzenia przy pomocy elektrozaworu. Po usunięciu awarii, ze względów bezpieczeństwa i wobec konieczności poinformowania użytkowników, odblokowanie elektrozaworu nie na- ną konstrukcję, między innymi elektrozawory konstrukcji normalnej, do zastosowań ogólnych, np. w domach, blokach.

Innym rodzajem mogą być elektrozawory w wykonaniu przeciwwybuchowym Ex, do zastosowania w strefach zagrożonych wybuchem. Dobór elektrozaworu uzależniony jest od używanego systemu, instalacji, w jakiej zawór ma pracować, oraz medium, jakie ma być transportowane instalacją.

\section{Systemy zabezpieczające przed migracją gazu do wnętrza budynków}

Jak wspomniano wcześniej, zdarzają się wypadki związane $\mathrm{z}$ wybuchem gazu w budynkach, w których nie ma instalacji gazowej. Na rynku istnieje wiele rozwiązań pozwalających na uszczelnienie przejść instalacji do wnętrz budynku. Rozwiązania systemowe nie są jednak wystarczające, aby zapobiec takim sytuacjom. W Instytucie Nafty i Gazu - Państwowym Instytucie Badawczym zrealizowa- na została praca, której celem było opracowanie warunków technicznych dla sposobów ochrony budynków przed migracją gazu wzdłuż instalacji przez fundamenty oraz ściany do ich wnętrza. Przedstawiono również propozycję systemu gazoszczelnego przejścia instalacji przez zewnętrzną przegrodę obiektu budowlanego, zaopatrzoną w element odgazowujący.

\section{Polimeryzacja przewodów instalacji gazowych}

Dość częstym powodem występowania nieszczelności w instalacjach gazowych są połączenia gwintowane. Połączenia te $\mathrm{w}$ instalacjach uszczelniane były szczeliwem przy pomocy pokostu lub minii. Materiały te wysychają, przez co zmniejszają swoją objętość, powodując rozszczelnienie połączeń gwintowanych. Obecnie gaz przesyłany instalacjami jest bardziej suchy, co stanowi kolejną przyczynę wysychania uszczelnień w połączeniach. Usunięcie przyczyn takich awarii jest moż- liwe, lecz często kosztowne, wymagające pozwoleń budowlanych. Najpopularniejsze rozwiązanie to wymiana instalacji na nową poprzez wykonanie połączeń spawanych lub ponowne wykonanie połączeń gwintowanych (ich powtórne uszczelnienie). Na rynku pojawiły się również nowoczesne metody uszczelnień takich instalacji, niewymagające uzyskiwania pozwoleń na budowę oraz znacząco ograniczające koszty związane $\mathrm{z}$ wymianą instalacji na nową. 
Rozwiązaniem takim jest polimeryzacja. To metoda nieinwazyjna, bezpieczna, przywracająca sprawność instalacji gazowej. Przeprowadzenie takiej czynności zajmuje kilka dni, środek do wykonania uszczelnienia jest sporządzany na bazie wody i nie zawiera substancji niebezpiecznych, a sam proces traktuje się jako bieżącą konserwację instalacji. Zakres głównych robót polimeryzacyjnych to:

- wyłączenie dopływu gazu,

- odłączenie gazomierza i odbiorników gazowych,

- wymiana zaworów na kulowe,

- usunięcie odwadniaczy (jeśli istnieją),

- przedmuchanie instalacji gazem obojętnym, np. azotem,

- wykonanie połączenia tymczasowego w miejsce gazomierza,

- przygotowanie instalacji do napełnienia emulsją,
- napełnienie instalacji polimerem,

- opróżnienie instalacji z emulsji, czyszczenie i osuszanie,

- wykonanie próby ciśnieniowej,

- montaż gazomierza i odbiorników,

- zagazowanie instalacji,

- uruchomienie odbiorników,

- sprawdzenie szczelności instalacji,

- prace konserwacyjne.

Przedstawione czynności to czynności podstawowe, natomiast szczegóły dostępne są w instrukcjach wykonywania robót polimeryzacyjnych przygotowanych przez producenta systemu.

Do tej pory wykonano szereg takich czynności, zakończonych pełnym sukcesem, tzn. przywróceniem szczelności instalacji gazowych na następne lata. System ten posiadał certyfikat wydany przez INiG - PIB.

\section{Nowoczesne materiały do budowy instalacji gazowych}

Materiały, z jakich można wykonać instalacje gazowe, oraz rodzaje połączeń określone są w europejskiej normie EN 1775:2007 (polskie wydanie PN-EN 1775:2009) [13].

Obecnie w Polsce przepisy [12] dopuszczają budowę instalacji gazowych przy wykorzystaniu materiałów i połączeń przedstawionych poniżej:

- rur miedzianych twardych łączonych lutem twardym,

- rur miedzianych twardych łączonych przy pomocy złączek zaprasowywanych z miedzi i stopów miedzi,

- rur stalowych łączonych poprzez spawanie,

- rur stalowych łączonych przy pomocy kształtek gwintowanych z żeliwa białego.

Na rynku UE dopuszczone są również inne materiały i systemy zawarte w normie EN 1775:2007, z jakich można wykonać instalacje gazowe. Rozwiązaniami takimi są instalacje:

- z rur wielowarstwowych z PE lub PEX,

- z rur falistych ze stali nierdzewnej.

Instalacje $z$ rur wielowarstwowych z PE lub PEX są prostsze i szybsze do wykonania oraz posiadają mniej połączeń. Zaletą ich stosowania jest możliwość gięcia ręcznego rur lub za pomocą odpowiedniego przyrządu, jak również odporność na korozję. Rury te są mniej odporne niż rury stalowe czy miedziane na uszkodzenia mechaniczne i wysoką temperaturę, ale ze względu na mniejszą liczbę połączeń są mniej narażone na rozszczelnienia. Przy korzystaniu z rur wielowarstwowych z PE lub PEX zaleca się stosowanie dodatkowych zabezpieczeń temperaturowych (termozaworów aktywowanych wzrostem temperatury otoczenia) lub zaworów odcinających przy nagłym wzroście przepływu gazu. Rury takie składają się z wielu warstw: polietylen/PEX - klej - aluminium - klej - polietylen/PEX, co przedstawiono na rysunku 5.

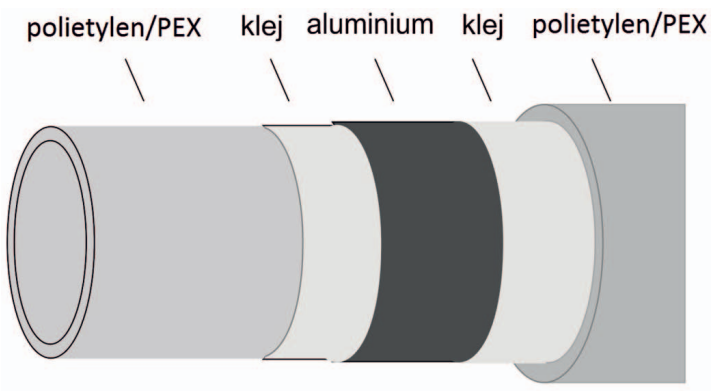

Rys. 5. Konstrukcja rur wielowarstwowych z PE lub PEX

Rury wielowarstwowe oraz rury faliste ze stali nierdzewnej zgodnie z normami unijnymi dozwolone są po zastosowaniu dodatkowych zabezpieczeń, np. zaworów reagujących na podwyższoną temperaturę czy nagły wyciek gazu.

Połączenia rur realizowane są zazwyczaj za pomocą złączek zaprasowywanych uszczelnianych o-ringiem. Przejścia przez ściany budynków powinny być wykonane z użyciem tulei osłonowych z tworzyw sztucznych. Zabrania się łączenia rur wewnątrz ścian.

Możliwością stosowania w instalacjach gazowych systemu rur wielowarstwowych z tworzyw sztucznych zajmowano się w INiG - PIB [10].

Z przeprowadzonych analiz wynika, że wymagania, jakie powinny spełniać rury wielowarstwowe, to:

- wytrzymałość na ciśnienie wewnętrzne,

- zdolność do utrzymania przyczepności międzywarstwowej,

- odporność na promieniowanie UV,

- odporność warstw zewnętrznych na uszkodzenia mechaniczne,

- ograniczenia na odkształcenia wzdłużne,

- zapewnienie odpowiedniej barwy zewnętrznej warstwy. 
Pod względem ekonomicznym nowe materiały mogą konkurować z tradycyjnymi rurami stalowymi i miedzianymi. Redukują wpływ na środowisko w porównaniu z rurami metalowymi. Ze względu na bezpieczeństwo wykazują podobny poziom, jednak w niektórych przypadkach koniecz- ne jest użycie dodatkowych zabezpieczeń, np. zaworów reagujących na nagły wypływ gazu.

$\mathrm{Na}$ innych rynkach, np. w USA czy Japonii, dopuszczony do stosowania został system $\mathrm{z}$ rur falistych ze stali nierdzewnej z zewnętrzną powłoką polietylenową lub PVC [8].

\section{Podsumowanie}

Reasumując, można stwierdzić, że główną przyczyną wypadków związanych z użytkowaniem instalacji gazowych są zdarzenia losowe (rozszczelnienie), nieprawidłowa obsługa urządzeń i brak kontroli okresowych instalacji gazowych.

Brak wyposażenia instalacji gazowych w systemy/instalację pozwalające na szybkie zamknięcie dopływu gazu do budynku może być powodem nagromadzenia się gazu, w wyniku czego może nastąpić jego wybuch. Wbrew zapisom w rozporządzeniu [12] systemy takie powinny być dozwolone (lub nakazane) do stosowania w każdym miejscu, w którym poprawiłyby bezpieczeństwo.

Przy użytkowaniu instalacji gazowych na gaz płynny propan-butan (butli gazowych do $11 \mathrm{~kg}$ ) przyczyną wypadków związanych z użytkowaniem tych urządzeń są najczęściej wadliwe zawory butli, brak uszczelek, zły stan techniczny butli, brak kontroli szczelności instalacji po ich pod- łączeniu/wymianie lub wadliwe podłączenie. Nieprawidłowości dotyczą również niewłaściwego przechowywania butli, narażania ich na wysokie temperatury i przechowywania w miejscach niedozwolonych.

Stare instalacje gazowe posiadające połaczenia gwintowane powinny być poddane procesom uszczelniania lub wymiany na nowe. Wykorzystanie nowych materiałów do wykonywania instalacji, stosowanych już w krajach Europy i w USA [8], pozwoliłoby na łatwiejsze i szybsze wykonywanie instalacji lub eliminację dodatkowych połączeń, będących często miejscem rozszczelnienia instalacji. Wprowadzenie obowiązku stosowania detektorów tlenku węgla z sygnalizacją akustyczną mogłoby również zmniejszyć negatywne skutki nieprawidłowego spalania paliwa gazowego przez urządzenia, spowodowanego przez wadliwe instalacje wentylacyjne.

Prosimy cytować jako: Nafta-Gaz 2017, nr 6, s. 411-421, DOI: 10.18668/NG.2017.06.06

Artykuł nadesłano do Redakcji 8.12.2016 r. Zatwierdzono do druku 23.05.2017 r.

Artykuł powstał na podstawie pracy statutowej pt.: Analiza możliwości poprawy bezpieczeństwa instalacji gazowych - praca INiG - PIB na zlecenie MNiSW; nr zlecenia: 0090/GP/2016, nr archiwalny: DK-4100-81/16.

\section{Literatura}

[1] Baryłka J., Baryłka A.: Katastrofy budowlane zaistniałe w Polsce w 2013 r. Inżynieria Bezpieczeństwa Obiektów Antropogenicznych 2014, nr 1, s. 29-38.

[2] Bednarek R.: Wybuch gazu w Rawie. Serwis Naszemiasto.pl, 4.09.2015, http://zdunskawola.naszemiasto.pl/artykul/wybuchgazu-w-rawie,3499867,art,t,id,tm.html (dostęp: 9.10.2016).

[3] Bezpieczeństwo eksploatacji urządzeń, instalacji i sieci gazowych, http://kursyzawodowe.pl/files/1714/1890/8208/Materialy do pobrania - g3.pdf (dostęp: 8.10.2016).

[4] Bezpieczny gaz. Portal Se.pl, 1.07.2010, http://www.se.pl/twoje-pieniadze/gaz-twoja-dobra-energia/bezpieczny-gaz_144564. html (dostęp: 8.10.2016).

[5] Demusiak G.: Nowe metody kontroli szczelności sieci i instalacji gazu ziemnego, z wykorzystaniem ręcznych detektorów laserowych do zdalnego wykrywania wycieków metanu. Nafta-Gaz 2010, nr 4, s. 287-296.

[6] Korzus M.: Samobójca wysadził dom. Portal Se.pl, 23.11.2009, http://www.se.pl/wiadomosci/polska/samobojca-wysadzidom_119734.html (dostęp: 22.10.2016).

[7] Markiewicz M., Stochaj P.: Ochrona katodowa zbiorników za pomoca anod galwanicznych. Nafta-Gaz 2010, nr 6, s. 493-499.

[8] Orange \& Rockland Pike County Light \& Power Co.: Natural Gas Installation Standards Handbook. 2015 Edition.
[9] Szer J.: Katastrofy budowlane spowodowane wybuchem gazu. XXVII Konferencja Naukowo-Techniczna, Awarie Budowlane 2015, s. 121-130.

[10] Wróblewska A.: Ocena możliwości stosowania w instalacjach gazowych systemów rur wielowarstwowych z tworzyw sztucznych. Nafta-Gaz 2010, nr 7, s. 597-601.

[11] Zatrucie tlenkiem węgla. Objawy zatrucia tlenkiem węgla. Serwis PoradnikZdrowie.pl, http://www.poradnikzdrowie. pl/sprawdz-sie/ciekawostki/zatrucie-tlenkiem-wegla-objawyzatrucia-tlenkiem-wegla_40845.html (dostęp: 26.10.2016).

\section{Akty prawne i normatywne}

[12] Obwieszczenie Ministra Infrastruktury i Rozwoju z dnia 17 lipca 2015 r. w sprawie ogłoszenia jednolitego tekstu rozporządzenia Ministra Infrastruktury w sprawie warunków technicznych, jakim powinny odpowiadać budynki i ich usytuowanie (Dz.U. poz. 1420).

[13] PN-EN 1775:2009 Dostawa gazu - Przewody gazowe dla budynków. Maksymalne ciśnienie robocze równe 5 bar lub mniejsze - Zalecenia funkcjonalne.

[14] PN-M-34507:2002 Instalacja gazowa - Kontrola okresowa.

[15] Rozporządzenie Ministra Gospodarki, Pracy i Polityki Społecznej z dnia 26 lutego 2004 r. zmieniające rozporządzenie w sprawie bezpieczeństwa i higieny pracy przy magazyno- 
waniu, napełnianiu i rozprowadzaniu gazów płynnych (Dz.U. $\mathrm{Nr}$ 43, poz. 395).

[16] Rozporządzenie Ministra Gospodarki, Pracy i Polityki Społecznej z dnia 28 kwietnia 2003 r. (Dz.U. Nr 89, poz. 828 z późn. zm.).

[17] Rozporządzenie Ministra Spraw Wewnętrznych i Administracji z dnia 7 czerwca 2010 r. w sprawie ochrony przeciwpożarowej budynków, innych obiektów budowlanych i terenów (Dz.U. Nr 109, poz. 719).

[18] Rozporządzenie Ministra Spraw Wewnętrznych i Administracji z dnia 16 sierpnia 1999 r. w sprawie warunków technicznych użytkowania budynków mieszkalnych (Dz.U. Nr 74, poz. 836).
[19] Ustawa z dnia 7 lipca 1994 r. - Prawo budowlane (tekst jednolity, Dz.U. z 2016 r. poz. 290).

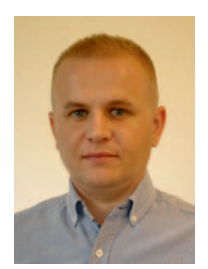

Mgr inż. Tomasz MINOR

Główny specjalista inżynieryjno-techniczny w Zakładzie Przesyłania i Dystrybucji Gazu. Instytut Nafty i Gazu - Państwowy Instytut Badawczy ul. Lubicz 25 A

31-503 Kraków

E-mail: tomasz.minor@inig.pl

\section{OFERTA}

\section{ZAKŁAD PRZESYŁANIA I DYSTRYBUC]I GAZU}

Zakres działania:

- badania laboratoryjne rur, kształtek, armatury z tworzyw sztucznych oraz armatury metalowej i powłok antykorozyjnych, prowadzone dla potrzeb certyfikacji i aprobat technicznych;

- ocena stopnia zagrożenia korozyjnego gazociagów stalowych oraz ocena stanu technicznego izolacji gazociągów stalowych metodami bezwykopowymi;

- ocena efektywności metod rekonstrukcji sieci dystrybucyjnych gazu;

- opracowanie projektów przepisów związanych z budową i użytkowaniem sieci gazowych;

- opracowanie lub opiniowanie projektów norm dotyczących sieci i instalacji gazowych;

- badania z zakresu współpracy ośrodka gruntowego z siecią gazową na terenach górniczych;

- $\quad$ prowadzenie specjalistycznego szkolenia kadr, głównie w zakresie budowy sieci gazowych z polietylenu;

- $\quad$ wspomaganie przemysłu we wdrażaniu nowych rozwiązań technicznych oraz opracowywanie ekspertyz i analiz;

- badania laboratoryjne metalowej armatury odcinającej do systemów i instalacji wodociągowych, baterii mechanicznych, natrysków i przewodów natryskowych oraz systemów rur wielowarstwowych do instalacji wody ciepłej i zimnej;

- $\quad$ ocena jakości połączeń zgrzewanych rur i kształtek z PE na potrzeby kwalifikacji personelu zgrzewającego wg normy PN-EN 13067 w Laboratorium Uznanym przez UDT - Świadectwo Uznania Laboratorium Tworzyw Sztucznych nr LBU-286/12-16.

Kierownik: mgr inż. Piotr Szewczyk

Adres: ul. Bagrowa 1, 30-733 Kraków

Telefon: 126177442

Faks: 126531665

E-mail: piotr.szewczyk@inig.pl 